Article

\title{
Business Area Changes and Entrepreneurial Persistence in Ecology- and Food-Related Industries: Knowledge Heterogeneity and Emotion Perspectives
}

\author{
Hongmin Chen ${ }^{1}$, Fu-Sheng Tsai ${ }^{2,3, *(1)}$ and Han-Chang Ling ${ }^{4}$ \\ 1 ANTAI College of Economics and Management, Shanghai Jiao Tong University, Shanghai 200240, China; \\ hmchen@sjtu.edu.cn \\ 2 Loonguard Research Institute, Guangzhou 510000, China \\ 3 Department of Business Administration, Cheng Shiu University, Kaohsiung 83347, Taiwan \\ 4 Graduate Institute of Technology and Innovation Management, National Chengchi University, \\ Taipei 11605, Taiwan; drfstsai@hotmail.com \\ * Correspondence: fusheng_tsai@hotmail.com; Tel.: +86-7-731-0606
}

Received: 15 February 2018; Accepted: 15 March 2018; Published: 23 March 2018

\begin{abstract}
Entrepreneurs' changes to different business areas can be viewed as shifts in entrepreneurial knowledge domains (e.g., from restaurant to food waste processing firm as an ecological helping business). From a sample of 73 representative entrepreneurs, we present a study of the impact of such area changes on the persistence of entrepreneurship (i.e., the degree an entrepreneur remains in entrepreneurial activities). Furthermore, two mediators, managerial experience and insecurity, and two moderators, positive and negative affect, were proposed and examined to make a more comprehensive theoretical inference of the relationship between area difference and persistence. The results revealed that, counter-intuitively, area difference was significantly and positively associated with entrepreneurial persistence. The mediation effects of managerial experience and psychological insecurity were also confirmed. However, only the moderation of positive affect was effective. Based on the knowledge heterogeneity and entrepreneurial emotion perspectives, academic and practical implications for inter-temporal dynamics of entrepreneurship are discussed.
\end{abstract}

Keywords: business area difference; positive and negative affect; insecurity; managerial experience; persistence; knowledge heterogeneity; emotion; ecology

\section{Introduction}

The knowledge-based economy rewards professionals who exploit experience and expertise for exploring new opportunities to create valued businesses [1-7]. Regions, industries, and businesses have strongly emphasized the development and management of high-quality human capital, among which entrepreneurs are key actors characterizing knowledge processing, creativity, and innovation capabilities [8]. Entrepreneurs are professionals whose career development are special and deserve in-depth investigation e.g., [9]. The decisions and actions of an entrepreneur often leaves great impact on the developmental trajectory of a new venture [10]. In such a context, knowledge is vital for the entire entrepreneurial life cycle, in that valuable knowledge facilitates entrepreneurial decisions and action, and thus may be a source of entrepreneurial competitive advantage [11].

Against this backdrop, however, many entrepreneurs cannot realize their dreams in their initial operating business area. Even more would not persist when facing dramatic changes, uncertainty, and failures [12] - they give up entrepreneurship or jump to other business area(s) for another trial. Two critical issues emerge for understanding such phenomena. For the first issue, the gap between knowledge domains of the old and new areas impose challenges in entrepreneurship implementation. 
Entrepreneurs may motivate themselves to change business areas like serial entrepreneurs [13], they may change actively but have not been ready yet, or there are also examples for reluctant changing of business areas. Self-motivated or forced to change to a new business area, entrepreneurs must acquire or develop new knowledge to manage and respond to new situations, which brings even more difficulty for entrepreneurs to persist in entrepreneurship. For the second issue, the entrepreneurs' psychological states should be jointly articulated with the aforementioned knowledge-oriented issue [14]. Psychological state either facilitates or impedes entrepreneurship, as it responds to the instability associated with start-up ventures (e.g., area change), together with difficult decisions that entrepreneurs may encounter $[15,16]$. These psychological factors are also critical in influencing entrepreneurial cognition [17], which is highly related to knowledge processing [18,19].

Following the discussion above, three critical knowledge- and psychology-based factors could be theorized as the key mediators/moderators in the relationship between area difference and entrepreneurial persistence. On the one hand, managerial experience is valuable for entrepreneurship implementation because it constitutes an important foundation for entrepreneurial thinking (Krueger, 2007) and opportunity recognition [20], by influencing the approaches that entrepreneurs choose to achieve entrepreneurship [21] and facilitating entrepreneurial learning [22].

On the other hand, psychological states have an impact on the cognitive mechanisms by which entrepreneurs interpret and enact business $[23,24]$. Among the significant psychological factors at play are the feelings of insecurity and positive and negative affect. Insecurity may be a potential barrier to more proactive entrepreneurial activities such as creative proposals or service innovation [25], or it may impede rational decision making [16]. Emotional affect, whether positive or negative, describes a human being's experience of positive or negative emotion by interacting with surrounding people. Affectivity is a contingent, if not decisive, factor in the relationships between entrepreneurial characteristics, endorsement, actions, and outcomes.

In sum, few have systematically and empirically investigated whether entrepreneurs vary in persistence if they start a new business in a relatively unfamiliar area that represents a different knowledge domain. We further elaborated and tested this question with the intervention of managerial experiences, insecurity, and positive and negative affect. Because entrepreneurial motivation and experience are critical to entrepreneurs' abilities when learning and discovering unfamiliar situations [5], managerial experience and the psychological-emotional factors together may serve as contingent factors. Here, we proposed the following hypotheses.

Hypothesis 1. Area difference is positively associated with entrepreneurial persistence.

Hypothesis 2. Positive affect positively moderates the relationship between area difference and persistence.

Hypothesis 3. Negative affect negatively moderates the relationship between area difference and persistence.

Hypothesis 4. Feelings of insecurity mediate the relationship between area difference and persistence.

Hypothesis 5. Managerial experience mediates the relationship between area difference and persistence.

\section{Materials and Methods}

We based our study in Taiwan, which is an entrepreneurship-intensive economy [26,27]. Because our study focused on business area differences in ecological industries (e.g., food waste processing, organic farms, recycling firms, ecological technology, system support, etc.) that pre-set a difficult situation for researchers to collect data from entrepreneurs, we adopted a purposive sampling approach. For representativeness, we based our sample structure on a list of the top 300 active entrepreneurs registered in and suggested by the Chinese Youth Career Development Association (CYCDA), which is the largest association for entrepreneurs in Taiwan. Despite its title, the CYCDA consults for 
entrepreneurs with a wide age range and levels of other demographic attributes. The criterion for potential entrepreneur raters to have experience of changing business areas has limited the total possible number of raters to 72 entrepreneurs out of the 300 . Because of the intrapersonal nature of the overall conceptual framework and major constructs, data collection from the same source is inevitable. We nonetheless adopted some pre-ante methods suggested by [28] to help minimize same-source biases. Furthermore, to facilitate raters' understanding of the questionnaire items and to answer questions instantly, the surveys were administrated through face-to-face interviews by well-trained research assistants. Because we focused on entrepreneurs' actions, knowledge, and psychological states, variances above the individual level of analysis need to be excluded. For example, we only include those entrepreneurs who have created their ventures alone, in order to exclude variance from the influences of co-founders as a team.

\section{Measurement}

Control variables: Because all of our variables are mainly subjective, we try to eliminate potential biases related to the raters' initial perceptions and decisions on entrepreneurial persistence by controlling significant demographic attributes including age and gender. Professional factors that may also similarly influence persistence as area change and managerial experiences, including industry type (i.e., the current operating industry), educational diversity of entrepreneur (i.e., the scope/width of areas in which the entrepreneur has been educated), industry diversity (i.e., the number of industries in which the entrepreneur has worked, which, to some degree, has also controlled the effect of prior business area type), and functional diversity (i.e., the number of different functional areas in which the entrepreneur has worked), were also controlled. We follow the method of [29] to calculate all diversity-based scores.

Independent variable: Area difference is measured using an item that calculates the differences between the former and current industries in which the rater (entrepreneur) operates. The raters were asked to check off items from a list of industries with codes. The list was preliminarily judged, and scores were assigned for area and knowledge differences by five professors and practitioners of entrepreneurship.

Moderators and mediators: Positive and negative affect were measured with four items adapted from $[29,30]$. Items include the following: 'In the past few weeks, I often felt happy, excited, enthusiastic and active'; 'In the past few weeks, I often felt angry, dissatisfied, distrustful, and depressed'; and 'In the past few weeks, I have often felt angry, dissatisfied, distrustful, and depressed'. Managerial experience is measured by asking the entrepreneurs how long they have been serving as managers or for how long they previously served as managers at entrepreneurial or non-entrepreneurial companies (measured by month). Insecurity was measured with items adapted from [31] psychological safety scale. The scale consists of three items related to job-related insecurity. We adapted these items to describe the extent to which an entrepreneur feels s/he would lose or fail in the newly changed business. Items include the following: 'I think it is possible that I will lose this business for unexpected reasons'; 'I do not think I will lose this business' (reverse-coded item); and 'I am growing restless, worrying that this business may stop unexpectedly'.

Dependent variables: Persistence information is collected, first, by retrieving the secondary data from company records or news sources, regarding the length of entrepreneurs' new business foundations (by days and latter transformed into year as unit of analysis), and second, by providing illustrative scenarios of persistence or change (starting-up new, changing area again, or ending entrepreneurship) and asking the entrepreneurs how long (from the date of rating questionnaires) they believe that they can keep the business going. We average the two scores to include both the factual and motivational aspects of the measure. Similar to the strategy of many seminal organizational and finance studies assessing strategic, psychological or behavioral persistence, such a measure also benefits from the adoption of time-based calculation as a natural and accurate assessment, in comparison with questionnaire items that collect current feelings or thoughts. 


\section{Results}

Table 1 lists the descriptive statistics and correlations among major variables. We performed hierarchical regression analyses to examine the proposed moderation and mediation relationships. We found that area differences are positively associated with entrepreneurial insecurity $(\beta=0.07$, $p<0.1$ ), confirming our Hypothesis 1 (H1), which argues that the greater the area difference, the greater the persistence. Thus, H1 was supported, which supports our theoretical prediction that entrepreneurs may tend to prove their decision to shift and may want to learn new knowledge by entering into a new business area. Hypotheses 2 and 3 stated that positive and negative affect moderate the relationship between area difference and persistence. Three sub-models were analyzed. For base Model 1 in Table 2, we entered only the control variables. In Model 2, we entered the variable of area difference with control variables. In Model 3, the influence of positive and negative affect was incorporated by including these two variables and the two interaction terms between these two with the area difference. We found that positive affect significantly and positively moderates the relationship between area difference and insecurity $\left(\beta=0.17, p<0.01, \Delta \mathrm{R}^{2}=0.16, p<0.01\right)$. In other words, when positive affect increases, the increase in persistence due to area difference might become higher, which supports Hypothesis 2. However, we did not find a significant moderating influence of negative affect, leaving Hypothesis 3 unsupported. [32] further found that the self-employed (i.e., entrepreneurs) may be psychologically stronger in regulating negative emotions such as stress or fear of failure. Therefore, we may argue that when entrepreneurs have a positive affect, such an emotional state may help magnify the positive effect of area difference on persistence. With a negative affect, however, entrepreneurs may try to regulate negative feelings and avoid making decisions.

Hypotheses 4 and 5 stated the mediating effects of insecurity and managerial experience. Based on [33] approach, three sub-models were analyzed for each of the mediators (see Table 3: Models 2, 3, 5, 7 for insecurity; and Models 2, 4, 6, 8 for managerial experience). The results indicated that both the mediation effects of entrepreneurial insecurity and managerial experiences were confirmed. To fulfill mediation, first, the effect of the independent variable(s) needs to be significant on the dependent variable (Model 2: Area difference is significantly associated with persistence, $\beta=0.09$, $p<0.1$ ). Second, the effect of the mediator needs to be significant on the dependent variable (Model 3 for insecurity: $\beta=-0.29, p<0.01$; Model 4 for managerial experience: $\beta=0.31, p<0.01$ ). Third, the independent variable(s) should be significantly associated with the mediator(s) (Model 5 for area difference insecurity: $\beta=-0.28, p<0.05$; Model 6 for area difference managerial experience: $\beta=0.09$, $p<0.1$ ). Fourth, after the mediator(s) joining the full model together with the independent variable(s), the effect of the independent variable(s) should turn insignificant (model) (see Models 7 and 8). Both Hypotheses 4 and 5 were supported. 
Table 1. Descriptive statistics.

\begin{tabular}{|c|c|c|c|c|c|c|c|c|c|c|c|c|c|}
\hline & Mean & S.D. & 1 & 2 & 3 & 4 & 5 & 6 & 7 & 8 & 9 & 10 & 11 \\
\hline 1. Gender & 1.24 & 0.43 & & & & & & & & & & & \\
\hline 2. Age & 43.71 & 7.26 & -0.10 & & & & & & & & & & \\
\hline 3. Industry type & 1.61 & 0.64 & -0.28 & 0.40 & & & & & & & & & \\
\hline 4. EBD & 0.02 & 0.00 & 0.27 & -0.08 & -0.02 & & & & & & & & \\
\hline 5. IED & 0.01 & 0.01 & -0.20 & $-0.64 * *$ & 0.01 & 0.10 & & & & & & & \\
\hline 6. FED & 0.01 & 0.01 & -0.12 & $-0.63 * *$ & $-0.42 * *$ & 0.05 & $0.74 * *$ & & & & & & \\
\hline 7. Area differences & 1.73 & 1.1 & -0.04 & 0.15 & 0.15 & 0.06 & -0.08 & -0.21 & & & & & \\
\hline 8. Positive Affect & 4.99 & 0.86 & -0.13 & 0.07 & $0.23 *$ & $-0.28 *$ & -0.02 & -0.23 & -0.07 & & & & \\
\hline 9. Negative Affect & 3.25 & 1.02 & 0.09 & -0.03 & $-0.42 *$ & 0.21 & -0.04 & 0.24 & -0.09 & $-0.32 * *$ & & & \\
\hline 10. Managerial exp. & 22.37 & 50.48 & -0.16 & $0.34^{* *}$ & $0.29 *$ & -0.02 & -0.19 & -0.21 & 0.14 & 0.08 & $-0.30 *$ & & \\
\hline 11. Insecurity & 3.83 & 0.69 & -0.06 & -0.13 & -0.28 & -0.04 & 0.04 & 0.12 & $-0.29 * *$ & -0.01 & $0.41^{* *}$ & -0.24 * & \\
\hline 12. Persistence & 4.89 & 0.87 & 0.05 & -0.03 & 0.13 & 0.09 & 0.05 & -0.14 & 0.13 & 0.01 & $-0.39 * *$ & $0.26^{*}$ & -0.30 * \\
\hline
\end{tabular}

Table 2. Examination of two moderators.

\begin{tabular}{cccc}
\hline DV. IV & Persistence (Model 1) & Persistence (Model 2) & Persistence (Model 3) \\
\hline Constant & $4.88^{* * *}$ & $4.82^{* * *}$ & 7.15 \\
Gender & 0.10 & 0.11 & 0.12 \\
Age & -0.01 & -0.01 & -0.00 \\
Industry & 0.06 & 0.06 & -0.14 \\
EBD & 18.79 & 16.42 & 49.96 \\
IED & $44.92^{*}$ & $41.82^{*}$ & 38.34 \\
FED & $-55.62^{* * *}$ & $-51.19^{* *}$ & -48.13 \\
Area differences & & $0.07^{*}$ & $-0.88^{* *}$ \\
PosAff & & & $-0.40^{* * *}$ \\
NegAff & & & $-0.37^{* * *}$ \\
AD $\times$ PosAff & & & $0.17^{* *}$ \\
AD $\times$ NegAff & & 4.40 & 0.03 \\
F & 4.58 & 0.08 & 10.17 \\
$\mathrm{R}^{2}$ & 0.07 & $0.01^{* * *}$ & 0.25 \\
$\Delta \mathrm{R}^{2}$ & $0.07^{* * *}$ & & $0.16^{* * *}$ \\
\hline
\end{tabular}

Note: EBD = Education background diversity; IED = Industrial experience diversity; FED = Functional experience diversity; PosAff = Positive affect; NegAff = Negative affect * $p<0.1$, $* * p<0.05,{ }^{* * *} p<0.01$. 
Table 3. Examination of two mediators.

\begin{tabular}{|c|c|c|c|c|c|c|c|c|}
\hline DV & Persistence & Persistence & Persistence & Persistence & Insecurity & Mgr. Exp. & Persistence & Persistence \\
\hline IV & (Model 1) & (Model 2) & (Model 3) & (Model 4) & (Model 5) & (Model 6) & (Model 7) & (Model 8) \\
\hline Constant & $4.88^{* * *}$ & $4.82 * * *$ & $4.88^{* * *}$ & $5.26^{* * *}$ & $5.09^{* * *}$ & $-80.08 * *$ & $6.66^{* * *}$ & $5.21^{* * *}$ \\
\hline Gender & 0.05 & 0.05 & 0.00 & 0.08 & $-0.16^{* * *}$ & -0.09 & 0.01 & 0.08 \\
\hline Age & -0.11 & -0.11 & -0.11 & $-0.17^{* *}$ & -0.00 & $0.21 * *$ & -0.12 & $-0.18^{* *}$ \\
\hline Industry & 0.04 & 0.04 & -0.06 & -0.03 & $-0.36^{* * *}$ & $0.24^{* * *}$ & -0.06 & -0.03 \\
\hline EBD & 0.05 & 0.05 & 0.05 & 0.04 & 0.00 & 0.02 & 0.05 & 0.04 \\
\hline IED & $0.25 * *$ & $0.23 * *$ & $0.28 * *$ & $0.31 * *$ & 0.14 & $-0.20 * *$ & $0.27 * *$ & $0.29 * *$ \\
\hline FED & $-0.36^{* * *}$ & $-0.33^{* *}$ & $-0.40^{* * *}$ & $-0.41^{* * *}$ & $-0.20 * *$ & $0.18^{* *}$ & $-0.39 * * *$ & $-0.39 * * *$ \\
\hline Area differences & & $0.09 *$ & & & $-0.28^{* *}$ & $0.09 *$ & 0.01 & 0.07 \\
\hline Insecurity & & & $-0.29 * * *$ & & & & $-0.29 * * *$ & \\
\hline Managerial experience & & & & $0.31^{* * *}$ & & & & $0.31^{* * *}$ \\
\hline F & $4.58^{* *}$ & $4.40^{* * *}$ & $8.78^{* * *}$ & $4.58^{* * *}$ & $10.16^{* * *}$ & $10.78^{* * *}$ & $7.67^{* * *}$ & $8.19^{* * *}$ \\
\hline $\mathrm{R}^{2}$ & 0.07 & 0.08 & 0.15 & 0.16 & 0.17 & 0.16 & 0.15 & 0.16 \\
\hline$\Delta \mathrm{R}^{2}$ & $0.07^{* * *}$ & 0.01 * & $0.08^{* * *}$ & $0.08^{* * *}$ & $0.07^{* * *}$ & $0.01 *$ & $0.07^{* * *}$ & $0.08^{* * *}$ \\
\hline
\end{tabular}

Note: EBD = Education background diversity; IED = Industrial experience diversity; FED = Functional experience diversity ${ }^{*} p<0.1^{* *} p<0.05^{* * *} p<0.01$. 


\section{Additional Analysis}

We conducted additional analysis to exclude the possibility that the moderators and the mediators may interact to affect persistence. In other words, we wish to ensure the legitimacy of the simple and independent mediation and moderation models and the logic of our theoretical inference. We conducted moderated mediation and mediated moderation analyses based on scholarly works from different approaches [34] using positive and negative affect as moderators and insecurity and managerial experience as mediators. For page limit, we put the information of these analyses in Appendix A. Briefly, no moderated mediation and mediated moderation effects were identified. Thus, it is acceptable to maintain separate moderation and mediation models in the current study.

\section{Discussion}

First, as entrepreneurship is dynamic as entrepreneurs may change between different knowledge/business areas, more studies should contribute by comparing continuous versus discontinued development of entrepreneurial knowledge and capability. Most studies of entrepreneurship adopted a dynamic capability perspective believing that development of knowledge and capability of the future is highly dependent in that in the past. However, more recent studies have pointed out that the development of entrepreneurial capability can be realized in both exploratory and exploitative fashion [35]. From the newer perspective, shifting to a highly familiar (i.e., a continuous development) and unfamiliar (i.e., a discontinued development) business/knowledge domains can both affect the evolution of dynamic entrepreneurial capabilities. With this understanding, studying business area difference as a chronic deviation of knowledge and capability can complement extant studies that assesses the cross-sectional heterogeneity of entrepreneurial knowledge and capability.

Second, entrepreneurs are inherently influenced by psychologically, cognitively or socially irrational factors e.g., [36], despite the rational factors such as managerial experience tested here. Future studies are encouraged to propose and examine more of such factors in affecting the entrepreneurial knowledge and capability development. More importantly, studies should carefully examine the interaction of rational and irrational factors in constituting the context of entrepreneurial behavior (e.g., the persistence here) and capability development.

Third, our results suggested very practically that entrepreneurs need to remain cheerful even if they are insecure. Moreover, feeling positively may not be an irrational factor because of its logic attribute. This adds even more interesting thinking since we test positive and negative affect in the same model (rational vs. irrational).

Several opportunities for future studies stemmed from the limited boundary of this paper. First, the sample size was small. However, such a small sample size is a result of more careful selection of representative respondents who fit the criteria outlined above. Beyond the present exploratory study, future research is encouraged to investigate relevant issues on different entrepreneur groups. Second, the present study investigated entrepreneurial persistence as an important outcome construct. However, we do not intend to judge the value of persistence per se. Persistence in entrepreneurial investments and actions may result in positive and/or negative returns for entrepreneurs. Though important, this issue is beyond the scope of the current study and may serve as an interesting direction for future research.

More issues are worth investigating in future studies. Additional variables of contextual contingencies may be examined to enrich our understanding of related phenomena. For example, considering factors associated with social relationships [37] as part of the present framework may further improve our understanding beyond individual level of analysis (e.g., the influence of partners, family, mentors, and even institutional forces). Moreover, searching for the true meaning of entrepreneurial insecurity may require researchers and practitioner-entrepreneurs to conduct a broader examination of the topic from different interdisciplinary perspectives. Is insecurity really a bad thing for an entrepreneur, or could it be beneficial if a sense of insecurity leads entrepreneurs to plan and implement tasks with more care, less overconfidence, and more thorough design and 
management? Moreover, our sample is drawn from Taiwan, where Chinese cultural roots may result in more conservative entrepreneurial perspectives on shifting businesses to new areas. Future studies should theorize and examine whether differences exist across various cultural groups of entrepreneurs, because of the differentiated nature of cognitions [38]. Finally, emotional regulation can be incorporated into the existing model. The present study examines the role of emotional elements but not the more proactive regulation or control of such elements [32]. Because entrepreneurship is inherently proactive, we encourage future studies to investigate the role of emotional regulation to provide more actionable implications. Although the small sample size and the use of $p<10 \%$ might cause concerns in external validity. However, our sample is comprised of a special group of persons that researchers could not easily reach (that is, entrepreneurs with persistence experiences in the premise of area change or not in ecology-related industries), and for the nature of the study is exploratory, this seems to be a necessary evil. Latter studies may also extend the unit-of-analysis up to entrepreneurial groups "fit" in knowledge and cognitions $[39,40]$ to see how they can co-create values during area transition.

\section{Conclusions}

How would business area change affect entrepreneurs' exit and persistence in entrepreneurship (i.e., persistence)? Our major variables are related to entrepreneurs' knowledge and knowledge structure. The present study tries to respond to this question by explicating conditions (moderators) and mechanisms (mediators) from knowledge-based and psychological (emotional) rationales. As most studies investigate persistence in existing business, we examined entrepreneurial persistence of the whole career as entrepreneurs shift between old and new businesses. Successful entrepreneurship depends largely on experiential knowledge and emotional stability because these strengths help transform entrepreneurial difficulties into manageable challenges and enable progress toward established goals $[17,25,41,42]$. Thus, studying persistence from knowledge and emotion perspectives is useful for opening a new avenue of research.

Author Contributions: H.C. wrote for the Literature Review; F.T. constructed the whole framework, and conducted and wrote for the data collection and analyses; H.L. finished the Discussions and Conclusion sections.

Conflicts of Interest: The authors declare no conflict of interest.

\section{Appendix A}

Table A1. Mediated Moderation and Moderated Mediation Tests.

\begin{tabular}{|c|c|c|c|c|c|c|}
\hline DV IV & $\begin{array}{l}\text { Persistence } \\
\text { (Model 1) }\end{array}$ & $\begin{array}{l}\text { Insecurity } \\
\text { (Model 2) }\end{array}$ & $\begin{array}{l}\text { Persistence } \\
\text { (Model 3) }\end{array}$ & $\begin{array}{l}\text { Persistence } \\
\text { (Model 4) }\end{array}$ & $\begin{array}{l}\text { Mgr. Exp. } \\
\text { (Model 5) }\end{array}$ & $\begin{array}{c}\text { Persistence } \\
\text { (Model 6) }\end{array}$ \\
\hline Constant & $6.45^{* * *}$ & $5.10^{* * *}$ & $3.57 * *$ & $6.45^{* * *}$ & $-91.55 *$ & $7.01^{* * *}$ \\
\hline Gender & 0.18 & $-0.27 * * *$ & 0.09 & 0.18 & -9.89 & $0.26^{* *}$ \\
\hline Age & -0.01 & 0.00 & $-0.02 *$ & -0.01 & $1.74 * * *$ & $-0.02 * *$ \\
\hline Industry & 0.08 & $-0.39^{* * *}$ & -0.07 & 0.08 & $21.44^{* * *}$ & -0.02 \\
\hline EBD & 32.57 * & -0.54 & $44.64^{* *}$ & $32.57 *$ & 1019.04 & 24.35 \\
\hline IED & $40.01^{* *}$ & 20.32 & 38.33 & $40.01^{* *}$ & $-2562.95^{* *}$ & $49.69^{* * *}$ \\
\hline FED & $-58.67^{* * *}$ & $-24.92 * *$ & $-63.44 *$ & $-58.67^{* * *}$ & $2011.20^{* *}$ & $-64.37^{* * *}$ \\
\hline Positive affect & $-0.41^{* * *}$ & 0.01 & 0.47 & $-0.41^{* * *}$ & -1.41 & $-0.39^{* * *}$ \\
\hline Area difference & $-0.97^{* * *}$ & -0.13 & $-0.77^{* * *}$ & $-0.97^{* * *}$ & -8.98 & $-0.90^{* * *}$ \\
\hline $\mathrm{AD} \times$ PosAff & $0.21^{* * *}$ & -0.01 & $0.16^{* * *}$ & $0.21 * * *$ & 2.78 & $0.19 * * *$ \\
\hline Insecurity & & & 0.71 ** & & & $0.01^{* * *}$ \\
\hline Insec. $\times$ PosAff & & & $-0.21^{* * *}$ & & & -0.00 * \\
\hline $\mathrm{F}$ & 6.23 & 7.87 & 9.35 & 6.23 & 7.78 & 8.75 \\
\hline $\mathrm{R}^{2}$ & $0.14^{* * *}$ & $0.17^{* * *}$ & $0.23^{* * *}$ & $0.14^{* * *}$ & $0.17^{* * *}$ & $0.22 * * *$ \\
\hline DV IV & $\begin{array}{l}\text { Persistence } \\
\text { (Model 1) }\end{array}$ & $\begin{array}{l}\text { Insecurity } \\
\text { (Model 2) }\end{array}$ & $\begin{array}{l}\text { Persistence } \\
\text { (Model 3) }\end{array}$ & $\begin{array}{l}\text { Persistence } \\
\text { (Model 4) }\end{array}$ & $\begin{array}{l}\text { Mgr. Exp. } \\
\text { (Model 5) }\end{array}$ & $\begin{array}{c}\text { Persistence } \\
\text { (Model 6) }\end{array}$ \\
\hline Constant & $4.79^{* * *}$ & $4.60 * * *$ & $5.11^{* *}$ & $4.79^{* * *}$ & $-98.21^{* *}$ & $5.32 * * *$ \\
\hline Gender & 0.09 & $-0.23^{* * *}$ & 0.03 & 0.09 & $-11.80^{*}$ & 0.16 \\
\hline Age & -0.00 & -0.01 & -0.00 & -0.00 & $2.36^{* * * *}$ & -0.01 \\
\hline Industry & $-0.17^{*}$ & $-0.20^{* * *}$ & $-0.21^{* *}$ & $-0.17^{*}$ & 11.53 * & $-0.20^{* *}$ \\
\hline EBD & $46.27^{* *}$ & -19.97 & $43.51 * *$ & $46.27^{* *}$ & $1953.69 *$ & $36.70 * *$ \\
\hline IED & 32.96 * & 23.54 * & $38.96^{* *}$ & $32.96 *$ & $-2852.72^{* * *}$ & $40.94 * *$ \\
\hline FED & $-33.46^{* *}$ & $-35.47^{* * *}$ & $-43.01^{* * *}$ & $-33.46^{* *}$ & $2736.16^{* * *}$ & $-40.33^{* * *}$ \\
\hline
\end{tabular}


Table A1. Cont.

\begin{tabular}{ccccccc}
\hline Negative affect & $-0.27^{* * *}$ & $0.32^{* * *}$ & 0.02 & $-0.27^{* * *}$ & $-9.87^{* *}$ & $-0.24^{* * *}$ \\
Area difference & $0.22^{* *}$ & -0.05 & $0.26^{*}$ & $0.22^{*}$ & $17.00^{* *}$ & -0.12 \\
AD $\times$ NegAff & -0.05 & -0.03 & $-0.07^{*}$ & -0.05 & -3.97 & $0.01^{* *}$ \\
Mgr. Exp. & & & -0.07 & & -0.00 \\
Mgr. Exp. $\times$ NegAff & & & -0.05 & & 10.15 & 11.63 \\
F & 10.15 & 15.63 & 9.44 & 0.32 & $0.23^{* * *}$ \\
$\mathrm{R}^{2}$ & $0.21^{* * *}$ & $0.29^{* * *}$ & $0.23^{* * *}$ & $0.21^{* * *}$ & 0.25 \\
\hline
\end{tabular}

Note: EBD = Education background diversity; IED = Industrial experience diversity; FED = Functional experience diversity; $\mathrm{AD}=$ Area difference; PosAff = Positive Affect; NegAff = Negative Affect; Mgr. Exp. = Managerial experiences ${ }^{*} p<0.1,{ }^{* *} p<0.05,{ }^{* * *} p<0.01$, , ${ }^{* * * *} p<0.001$

\section{References}

1. Audretsch, D.B.; Keilbach, M. The Theory of Knowledge Spillover Entrepreneurship. J. Manag. Stud. 2007, 44, 1242-1254. [CrossRef]

2. Chandler, G.N.; Lyon, D.W. Involvement in Knowledge-Acquisition Activities by Venture Team Members and Venture Performance. Entrep. Theory Pract. 2009, 33, 571-592. [CrossRef]

3. De Clercq, D.; Arenius, P. The Role of Knowledge in Business Start-up Activity. Int. Small Bus. J. 2006, 24, 339-358. [CrossRef]

4. Fernhaber, S.A.; McDougall-Covin, P.P. Venture Capitalists as Catalysts to New Venture Internationalization: The Impact of Their Knowledge and Reputation Resources. Entrep. Theory Pract. 2009, 33, 277-295. [CrossRef]

5. Marvel, M.R. Human Capital and Search-Based Discovery: A Study of High-Tech Entrepreneurship. Entrep. Theory Pract. 2013, 37, 403-419. [CrossRef]

6. Terjesen, S. Building a Better Rat Trap: Technological Innovation, Human Capital, and the Irula. Entrep. Theory Pract. 2007, 31, 953-963. [CrossRef]

7. Wensley, A.K.P.; Cegarra-Navarro, J.G.; Cepeda-Carrión, G.; Millán, A.G.L. How entrepreneurial actions transform customer capital through time: Exploring and exploiting knowledge in an open-mindedness context. Int. J. Manpow. 2011, 32, 132-150. [CrossRef]

8. Marvel, M.R.; Lumpkin, G.T. Technology Entrepreneurs' Human Capital and Its Effects on Innovation Radicalness. Entrep. Theory Pract. 2007, 31, 807-828. [CrossRef]

9. Terjesen, S. Senior women managers' transition to entrepreneurship: Leveraging embedded career capital. Career Dev. Int. 2005, 10, 246-259. [CrossRef]

10. Erçek, M.; Günçavd, O. Imprints of an Entrepreneur and Evolution of a Business Group, 1948-2010. Bus. Hist. 2016, 58, 89-110. [CrossRef]

11. Holcomb, T.R.; Ireland, R.D.; Holmes, R.M., Jr.; Hitt, M.A. Architecture of Entrepreneurial Learning: Exploring the Link among Heuristics, Knowledge, and Action. Entrep. Theory Pract. 2009, 33, 167-192. [CrossRef]

12. Holland, D.V.; Shepherd, D.A. Deciding to Persist: Adversity, Values, and Entrepreneurs' Decision Policies. Entrep. Theory Pract. 2013, 37, 331-358. [CrossRef]

13. Wright, M.; Robbie, K.; Ennew, C. Serial entrepreneurs. Br. J. Manag. 1997, 8, 251-268. [CrossRef]

14. Armstrong, S.J.; Hird, A. Cognitive Style and Entrepreneurial Drive of New and Mature Business Owner-Managers. J. Bus. Psychol. 2009, 24, 419. [CrossRef]

15. De Vries, K.; Manfred, F.R. The Anatomy of the Entrepreneur: Clinical Observations. Hum. Relat. 1996, 49, 853-883. [CrossRef]

16. Rauch, A.; Frese, M. Psychological approaches to entrepreneurial success: A general model and an overview of findings. In International Review of Industrial and Organizational Psychology; Cooper, C.L., Robertson, I.T., Eds.; Wiley: Hoboken, NJ, USA, 2000; pp. 101-142.

17. Mitchell, R.K.; Busenitz, L.; Bird, B.; Gaglio, C.M.; McMullen, J.S.; Morse, E.A.; Smith, J.B. The central question in entrepreneurial cognition research 2007. Entrep. Theory Pract. 2007, 31, 1-27. [CrossRef]

18. Mitchell, R.K.; Chesteen, S.A. Enhancing entrepreneurial expertise: Experiential pedagogy and theentrepreneurial expert script. Simul. Gaming 1995, 26, 288-306. [CrossRef]

19. Mitchell, R.K.; Mitchell, B.T.; Mitchell, J.R. Entrepreneurial Scripts and Entrepreneurial Expertise: The Information Processing Perspective, The Handbook of Entrepreneurship: The Entre-Preneurial Mind; Springer: New York, NY, USA, 2009. 
20. Shane, S.; Venkataraman, S. The Promise of Entrepreneurship as a Field of Research. Acad. Manag. Rev. 2000, 25, 217-226. [CrossRef]

21. Walske, J.M.; Zacharakis, A. Genetically Engineered: Why Some Venture Capital Firms Are More Successful Than Others. Entrep. Theory Pract. 2009, 33, 297-318. [CrossRef]

22. Mosey, S.; Wright, M. From Human Capital to Social Capital: A Longitudinal Study of Technology-Based Academic Entrepreneurs. Entrep. Theory Pract. 2007, 31, 909-935. [CrossRef]

23. Baron, R.A. Cognitive mechanisms in entrepreneurship: Why and when enterpreneurs think differently than other people. J. Bus. Ventur. 1998, 13, 275-294. [CrossRef]

24. Baron, R.A. The Role of Affect in the Entrepreneurial Process. Acad. Manag. Rev. 2008, 33, 328-340. [CrossRef]

25. Baer, M.; Frese, M. Innovation is not Enough: Climates for Initiative and Psychological Safety, Process Innovations, and Firm Performance. J. Organ. Behav. 2003, 24, 45-68. [CrossRef]

26. Fang, S.-C.; Tsai, F.-S.; Lin, J.L. Leveraging Tenant-Incubator Social Capital for Organizational Learning and Performance in Incubation Program. Int. Small Bus. J. 2010, 28, 90-113. [CrossRef]

27. Saxenian, A.L.; Li, C.-Y. Bay-to-bay strategic alliances: The network linkages between Taiwan and the US venture capital industries. Int. J. Technol. Manag. 2003, 25, 136-150. [CrossRef]

28. Podsakoff, P.M.; MacKenzie, S.B.; Lee, J.Y.; Podsakoff, N.P. Common Method Biases in Behavioral Research: A Critical Review of the Literature and Recommended Remedies. J. Appl. Psychol. 2003, 88, 879-903. [CrossRef] [PubMed]

29. Eisenberg, J.; James, K. The Relationship between Affect and Creativity in Organizations: The Roles of Affect Characteristics, Neuro-cognitive Mechanisms and Task Type. Res. Emot. Organ. 2005, 1, 241-261.

30. Kiefer, T. Feeling bad: Antecedents and consequences of negative emotions in ongoing change. J. Organ. Behav. 2005, 26, 875-897. [CrossRef]

31. Edmondson, A. Psychological Safety and Learning Behavior in Work Teams. Adm. Sci. Q. 1999, 44, 350-383. [CrossRef]

32. Patzelt, H.; Shepherd, D.A. Negative emotions of an entrepreneurial career: Self-employment and regulatory coping behaviors. J. Bus. Ventur. 2011, 26, 226-238. [CrossRef]

33. Baron, R.M.; Kenny, D.A. The moderator-mediator variable distinction in social psychological research: Conceptual, strategic, and statistical consideration. J. Personal. Soc. Psychol. 1986, 51, 1173-1182. [CrossRef]

34. Edwards, J.R.; Lambert, L.S. Methods for integrating moderation and mediation: A general analytical framework using moderated path analysis. Psychol. Methods 2007, 12, 1-22. [CrossRef] [PubMed]

35. O'Reilly, C.A., III; Tushman, M. Ambidexterity as a Dynamic Capability: Resolving the Innovato's Dilemma. In Research in Organizational Behavior; Brief, A.P., Staw, B.M., Eds.; Elsevier: Oxford, UK, 2008; Volume 28, pp. 185-206.

36. Coelho, M.P. Unrealistic Optimism: Still a Neglected Trait. J. Bus. Psychol. 2010, 25, 397-408. [CrossRef]

37. De Clercq, D.; Dimov, D.; Thongpapanl, T. The moderating impact of internal social exchange processes on the entrepreneurial orientation-performance relationship. J. Bus. Ventur. 2010, 25, 87-103. [CrossRef]

38. Mitchell, R.K.; Smith, J.B.; Morse, E.A.; Seawright, K.W.; Peredo, A.M.; McKenzie, B. Areentrepreneurial cognitions universal? Assessing entrepreneurial cognitions across cultures. Entrep. Theory Pract. 2002, 26, 9-32. [CrossRef]

39. Casali, G.L.; Perano, M.; Tartaglione, A.M.; Zolin, R. How business idea fit affects sustainability and creates opportunities for value co-creation in nascent firms. Sustainability 2018, 10, 189. [CrossRef]

40. Ngongoni, C.N.; Grobbelaar, S.S.S. Value co-creation in entrepreneurial ecosystems: Learnings from a Norwegian perspective. In Proceedings of the 2017 IEEE AFRICON: Science, Technology and Innovation for Africa, Cape Town, South Africa, 18-20 September 2017; pp. 707-713.

41. Cardon, M.S.; Foo, M.-D.; Shepherd, D.; Wiklund, J. Exploring the Heart: Entrepreneurial Emotion Is a Hot Topic. Entrep. Theory Pract. 2012, 36, 1-10. [CrossRef]

42. Wiklund, J.; Shepherd, D. Knowledge-based resources, entrepreneurial orientation, and the performance of small and medium-sized businesses. Strateg. Manag. J. 2003, 24, 1307-1314. [CrossRef]

(C) 2018 by the authors. Licensee MDPI, Basel, Switzerland. This article is an open access article distributed under the terms and conditions of the Creative Commons Attribution (CC BY) license (http:/ / creativecommons.org/licenses/by/4.0/). 